\title{
The Impact of ICT on the Demand for Skilled Labour:
}

\section{A cross-country comparison*}

\author{
Mary O’Mahony, Catherine Robinson and Michela Vecchi \\ National Institute of Economic and Social Research
}

\section{Corresponding author e-mail: kate.robinson@niesr.ac.uk}

JEL Classification : J23, J31, O33

Keywords: $\quad$ ICT $\quad$ skills labour demand technology

Approximate word count: 7,459

\begin{abstract}
This paper presents a cross-country comparative perspective on the impact of information technology on the demand for skilled labour. It employs a skills panel dataset, developed for four countries, comprising five or more skill categories for each country. The results indicate a significant difference in the nature of the relationship between changes in skill shares in the US compared to Europe (UK, France and Germany) and within these countries there is considerable heterogeneity. The findings imply that the US experienced a first mover advantage with ICT that resulted in a higher demand for skilled labour not (yet) matched in Europe.
\end{abstract}

\footnotetext{
* This paper was funded jointly by a grant from the 'Evidence Based Policy Fund' with contributions from HMTreasury/DTI/DfES and the European Commission 'Fifth Framework' program. The development of the skills database owes much to contributions from NIESR colleagues John Forth, Geoff Mason, and Lucy Stokes, Laurence Nayman and Johanna Melka at CEPII, Paris and Martin Falk at WIFO,previously at ZEW. We would also like to thank Nicholas Oulton, Sig Prais and colleagues at NIESR for comments.
} 


\section{Introduction}

Over the past 30 years the wage differential between high and low skilled workers has increased in the US and, to a lesser extent, in Europe. At the same time, the number of students entering higher education has been increasing in most developed economies worldwide (Autor et al, 1998; Riley and Young, 2000). These two factors together have led many economists to the conclusion that the skills premium has increased because the demands for skills by modern technology has increased faster than the supply. This paper considers the complementarities between human capital, technology use and technology adoption. We examine the relationship between human capital and technology at a disaggregated skill level, across four countries (the UK, the US, France and Germany), using both employment and wage share equations.

This paper uses uniquely diverse and disaggregated data at the industry level in each country, covering the period 1979-2000. These data cover the service sectors, in addition to manufacturing, where the impact of ICT is thought to have been greater. The skills data used in this paper are constructed on a more disaggregated level than found in the existing literature allowing us to consider the role of technology on the demand for intermediate skills, previously a 'black box' of labour demand. If in the long run, technology is deskilling, we would expect to see a gradual shift in the demand for labour through the intermediate categories as ICT knowledge becomes more codified and accessible as adoption takes place.

The US is considered to have enjoyed a first mover advantage in the adoption and diffusion of ICT, while the European countries joined the ICT revolution at a later stage. Institutionally, the UK is quite similar to the US in terms of flexible labour adjustment policies, low unemployment rates and large wage differentials. In France and Germany, on the other hand, the more rigid labour market institutions are considered to be at least one of the explanations for the persistently higher unemployment rate. It is argued that such differences can affect the way in which technology impacts on the demand for skills and therefore an analysis of the impact of ICT on relative skill demands may lead to different results and thus different policy implications in the four countries.

The next section reviews existing literature on skills and technology and the paper then goes on to set out the estimating equations within a general framework. Details on the data being used are then presented in section 4. The econometric results of employment and wage share equations are presented in section 5. In section 6 conclusions are drawn on the impact of information technology on skill demand.

\section{Skills and technology}

Much of the literature concerned with skill utilisation in the context of the introduction of information and communications technology (ICT) has focused on skill biased technical change. 
This in turn was driven from an empirical perspective, based increasing wage inequality in the US in the 1980s. Card and DiNardo (2002) describe skill biased technical change (SBTC) in general terms as a 'burst of new technology' that causes 'a rise in the demand for highly skilled workers that in turn leads to a rise in earnings inequality'. Skill biased technical change is defined as an increase in skilled labour's cost share. This needs to be distinguished from skilled labour augmenting technical progress whereby a technical advance increases the effective labour input of skilled rather than unskilled workers. The two concepts are related in that skill biased technical change can result from skilled labour augmenting technical change if the elasticity of substitution between skilled and unskilled labour exceeds one (Kahn and Lim, 1998). It can be argued that technical change is designed to be labour augmenting. Technical change should facilitate the production process and so make labour more productive, in other words, it should increase the effective labour input. Skill biased technical change is more than this however, since it results in a change in the labour input mix, increasing the demand for high skilled workers by a greater proportion than the low skilled.

When searching for the impact of skill biased technical change on the structure of wages and the labour force, the demand for skills cannot be considered in total isolation of supply conditions, therefore skilled biased technical change needs to be considered within a supply and demand framework. Acemoglu (2003) develops such a model and demonstrates how shifts in the demand and supply curves, in part a result of technology, affect the equilibrium of skilled labour. Shifts are unlikely to be solely determined by technological factors. Explanations for exogenous shocks include supply side factors such as the baby boom of the 1960s, as they entered the workforce in the 1970s and 1980s, and demand side shocks such as the oil crisis which suppressed global productivity growth ${ }^{1}$. In his model, Acemoglu (2003) proposes different technological responses, based on differences in the effects of institutions on wage setting; these, he argues, account for differences between national responses to technology shocks.

Whether or not technical change is skill biased has implications for the labour force, for approaches to training and education and other welfare consequences. Historically, changes in technology have been associated with deskilling the labour force in the longer run. The substitution of machines for skilled labour in the industrial revolution in the $19^{\text {th }}$ century and the move towards Fordist manufacturing techniques in the 1950s are the most widely cited examples ${ }^{2}$. In many respects, this has been less worrying from a societal perspective, since the unskilled are relatively harder to employ than skilled workers who are thought to be more adaptable to alternative

\footnotetext{
${ }^{1}$ Among other factors put forward are globalisation and increased openness of international trade (Autor, et al, 1998), changes in defence spending, and changes to labour market institutions and firm organisation (Caroli and Van Reenen, 2001).
} 
employment opportunities (Prais, 1986, p.98). Thus, technology has traditionally resulted in more opportunities for labour (as a whole), rather than less. Whether this will be the case with ICT remains to be seen but early indications suggest that it is more skill biased in nature than previous generic technologies. Much of the evidence is based on augmenting employment or wage share equations with an information technology term (Autor et al, 1998; Berman et al, 1998; Chun, 2003). However these findings have only been indicative of skill biased technological change since they may be the result of other factors that shift the relative positions of labour supply and demand curves. Recent empirical work on skill biased technical progress is summarised in Chennells and Van Reenen (1999) where they examine studies carried out at the industry, firm and the employee level. The econometric equations generally take the form of changes in wage or employment shares over time. Chennells and Van Reenen (op cit) find considerable support for SBTC across the whole range of studies.

A parallel literature has focused attention on the use of skilled labour to instigate organisational changes in the context of rapid adoption of ICT. For example in study based on firmlevel data, Bresnahan, Brynjolfsson and Hitt (2002) conclude that the increased demand for highskilled labour associated with ICT diffusion may in fact be more attributable to skill-biased organisational changes induced by ICT than to 'raw technical change' itself. Empirical studies of the impact of new work practices on firm performance suggest that productivity performance is highest in firms where investments in ICT equipment and skills training have been supported by complementary changes in work organisation (Black and Lynch, 2001). The flavour of this research is that having a workforce with general skills that complement new technology is important.

Evidence from cost share estimation shows that the share of skilled workers is positively related to ICT, thus supporting and complementing the organisational change literature. However it can be argued that there is a need to go beyond the standard cost share models to consider the dynamics of the process of any increased demand for skilled labour. Arguably, much of the observed skill bias may be a short run, adoption effect. In time, as the technology becomes more broadly accepted, the skill bias might disappear or the types of skills in demand may change ${ }^{3}$. Models of technology diffusion state that generally, adoption follows an S-curve (Geroski, 2000), with an initially slow start up period, and a later period of relatively slow adoption as the market reaches satiation point sandwiching a mid-period of rapid uptake. Whilst the structure of the process may be agreed, the speed at which this adoption takes place is not known, though it is likely to be faster for simpler technologies. Adoption is also likely to vary across countries, where market

\footnotetext{
${ }^{2}$ A different view is expressed in Goldin and Katz (1998) who portray technology as being inherently skill biased at least in the $20^{\text {th }}$ century.

${ }^{3}$ This argument seems particularly pertinent to ICT which at the outset required programmers and engineers, but the diffusion process, and particularly with the advent of Microsoft, facilitated the move to more general skilled workers.
} 
institutions differ considerably. These differences will be bound up in estimates of skilled biased technical progress if not taken into account separately.

An interesting paper in this respect is Chun (2003) where he argues the need to distinguish between the short run, adoption effect that ICT has on the demand for skills, and the longer run use effect that may be considered to be the 'real' change in skill bias. To incorporate this distinction into a modelling framework Chun uses an additional term, the average age of IT capital, on US data for 1960s-1990s within a Translog framework, to capture the adoption effect separately. Using a labour cost share function he concludes that as the new technology becomes fully implemented, firms can replace highly paid, highly educated workers with lower paid less educated workers.

In examining further the implications of Chun's argument it is worthwhile dividing the skill distribution further than has been usually the case in the skill biased technical change literature. Riley and Young (1999) examined the intermediate skill effect using data for the UK, US and Germany. A main conclusion of their study was that the high level of intermediate skills in Germany makes the lower end of the skill distribution more able to deal with changes in technology with the effect more apparent in services than manufacturing ${ }^{4}$. However, in a study that considers only intermediate skills in Germany, Jacobebbinghaus and Zwick (2003) found that there was a significant impact of technology on intermediate skill groups for the banking, real estate and insurance sectors, although elsewhere they found no discernible impacts.

Our paper uses more disaggregated skills categories than previously employed which allows for a detailed consideration of the nature of technology and the demand for skills. Following Chun (2003) it also includes an adoption variable and uses an (albeit simple) approach to examining changes in the demand for skilled labour across time.

\section{Model outline}

Wage and employment share equations are derived from cost and production functions, respectively ${ }^{5}$. In the literature discussed above a variety of functional forms are used; here we use the derivations from the Translog function. Starting with the wage share equation, the labour cost share of a specific skill group is defined as a function of the stock of quasi-fixed capital, real output and a variable to capture the impact of information technology. Note that the derivation of share equations based on a Translog production function include relative factor price terms to capture substitution between different types of workers. However, these terms are generally dropped from empirical analyses because they are likely to be endogenous (see further discussion of this below) with researchers relying on time dummies to pick up general wage movements.

\footnotetext{
${ }^{4}$ See also Prais and Wagner (1985).
} 
In addition to these standard variables a measure of technology adoption is included. In this paper, the ratio of high skilled Information Technology (IT) workers as a proportion of total workers in each industry is chosen as the adoption measure. It is assumed that these occupations (computer programmers, software engineers etc) ${ }^{6}$ are specifically linked to adoption of ICT since they involve very specific skills. But they are less likely to be the skills required to instigate organisational changes in using the new technology. Other measures of technology adoption have been used in related empirical works, such as the number of newly adopted technologies (Doms, Dunne and Troske 1997) and the average age of capital (Chun 2003).

Hence from the translog cost function and applying Shephard's lemma, labour cost share equations in first difference for each category of workers can be derived as:

$$
\Delta\left(\frac{W s_{j i}}{W T_{j}}\right)=\beta_{0}+\beta_{K} \Delta \ln \left(\frac{K_{j}}{Y_{j}}\right)+\beta_{I T} \Delta \ln \left(\frac{I K_{j}}{K_{j}}\right)+\beta_{A D}\left(\frac{I T H_{j}}{\operatorname{TotEmp}_{j}}\right)+\varepsilon_{j}
$$

where $W s_{i j}$ is the wage of an industry specific skill group, $W T_{j}$ is the total wage bill for a particular industry and other terms are as described above. Again $\frac{K_{j}}{Y_{j}}$ captures the degree of capital skill complementarity and $\frac{I K_{j}}{K_{j}}$ is used as a technology indicator. $\frac{I T H_{j}}{\operatorname{TotEmp}_{j}}$ is the proportion of IT workers over the sum of employment in that industry, to capture adoption, as discussed above. We assume that if the new IT technology is adopted, it will require a number of highly skilled IT engineers, therefore the ratio will be high and it will have a positive impact on the wage of higher skilled workers. During the adoption process the ratio will decrease, as the technology becomes more accessible to less skilled workers. Thus there should be a greater impact on the demand for less skilled workers. The derivation of this equation is based on the assumption of perfect markets but in practice it should be noted that it will also include the impact of market imperfections and distortions such as regulation and institutional arrangements.

In many studies equation (1) is estimated in employment shares rather than cost shares. Although strictly not capable of identifying skill biased technical progress, these equations convey some information on the relative demands for different types of workers and their correlation with information technology. In particular, wage share equations may fail to show any relationship with ICT if institutional rigidities or wage setting regulations constrain workers in greater demand from

\footnotetext{
${ }^{5}$ See for example Berndt (1990), p. 472, or Chennells and van Reenen (1999).

${ }^{6}$ Using the UK 1990s Standard Occupational Classification the included categories are: 126: Computer systems managers; 214: Software engineers; 320: Computer analysts, programmers; 490: Computer operators; and 526 Computer engineers, installation and maintenance. Since these categories encompass a wide range of skill levels we only include those with degrees or above in the adoption variable.
} 
reaping any additional benefit. For this reason we also estimate employment share equations of the form:

$$
\Delta\left(\frac{E s_{j i}}{E T_{j}}\right)=\beta_{0}+\beta_{K} \Delta \ln \left(\frac{K_{j}}{Y_{j}}\right)+\beta_{I} \Delta \ln \left(\frac{I K_{j}}{K_{j}}\right)+\varepsilon_{j}
$$

Where Es represents the employment in skill category $i$, for industry $j$, and ET is the total employment in industry $j$, and other terms are as in equation (1).

\section{Data sources}

The equations described above are estimated using an industry panel data, comprising annual series from 1979 to 2000 for 31 US industries and 27 UK industries, from 1982 to 2000 for 30 French industries and from 1979 to 1998 for 25 German industries. In each country industry coverage was for all non-agricultural market sectors (excluding health, education and public administration) but the division into sectors was dictated by the availability of investment series. Germany was included in the analysis only for employment shares, as wage data were unavailable for comparable skill categories.

Output is real value added and labour input is annual hours worked. The capital measure is divided into its ICT and its non-ICT components, measured using Tornqvist capital services indices comprising three assets categories within ICT capital (computers, software and communications equipment) and three within non-ICT capital (structures, non-ICT equipment and vehicles). Capital stocks were estimated for each asset using the perpetual inventory method, assuming exponential depreciation with rates which vary across industries but are assumed common in the same industry in the four countries. Indexes of capital services were then derived by weighting the growth rate of each asset type by its share in the nominal value of total capital services employing user costs rather than asset acquisition prices. US deflators, in particular the computer hedonic price index, adjusted for exchange rate movements, were employed for the UK and Germany, based on Oulton (2002). The French investment data for computers incorporate a hedonic adjustment. All data series are based on national accounts; for additional details see O’Mahony and deBoer (2002) and Timmer and O’Mahony (2002).

Measurement of skill proportions is difficult in an international context where training and educational systems vary. A mixture of qualifications and educational attainment are employed but these are allowed to vary across countries- for details see Mason et al (2002). Skill definitions and sources are presented in Table 1 along with employment shares at the beginning (1982) and the end (2000) of the period. This provides information on both levels in each category and changes in skill proportions over time. 


\section{Results}

Employment shares

Equation (2) was estimated separately for the US, UK, France and Germany and the results are presented in tables 2-5, respectively. Year dummy variables are included in all specifications. Two versions of equation (2) were estimated for each country, firstly for the whole time period, and secondly assuming a breakpoint in 1989. To allow the coefficients to vary between the two periods, time interactive terms were included. All data have been weighted by the average industry share of labour cost (Berman et al. 1994; Chun 2003). This gives more weight to larger industries and therefore avoids a likely source of heteroskedasticity in the data (Khan and Lim 1998). For all four countries estimation was carried out for all groups, imposing the restriction that the shares sum to one (or in the case of differenced equations, zero).

Table 2 shows results for US employment shares. The capital-skill complementarity term is both positive and significant for the higher skill group but significantly negative for high school graduates. In the case of ICT capital intensity there is a significant and positive impact for the three highest categories, but for those without qualifications, the coefficient is significantly negative. These results indicate that the high school graduate group is neutral to ICT intensity. When the time period is split, however, different results emerge. Thus the skill-capital complementarity is large and significant for the higher skilled for the 1990-2000 period only. A significant and negative impact for the early period for the high school graduates is also detected and the trend continues in the latter period, although the coefficient is smaller and less significant. The most interesting finding is that the positive impact of ICT capital intensity found for the entire period stems largely from the 1979-88 period, with the higher skilled workers experiencing the largest gain in share as a result of increases in ICT capital. Overall therefore the US employment results suggest a decrease in the rate of relative demand for skilled workers associated with ICT and the disappearance of the negative impact on the less skilled workers over time. Thus, by the latter period, the employment share equations suggest a neutral response of skill shares to ICT intensity.

Examining the UK results (Table 3) it can be seen that, skill-capital complementarity is concentrated in the two highest categories. ICT technology has very little impact on the higher skill groups though there is a significant and positive coefficient on the basic (NVQ21) qualification group. In model 2 it can be seen that the capital-skill complementarity in higher skilled categories is driven by the second half of the period. In contrast to the US results, whilst there is little evidence of ICT affecting skill shares in the overall and early period, the 1990s shows considerable evidence in support of skill biased technical change. Thus, the pattern of increased demand for highly skilled (and the decreased demand for the low skilled) associated with ICT in the 1980s in the US becomes apparent for the UK only in the 1990s, suggestive of a lagged response. 
In the case of France (Table 4), the employment shares of the highest intermediate skill category shows a significantly positive association with ICT with also a positive but weaker associatiation for the university graduate group. As for the US and UK, the coefficient on the ICT term is negative and significant for the no qualification group. There is little evidence of capital skill complementarity, except in the baccalaureate skill class. Again the results show that the ICT capital intensity variable has a strong and positive impact in the second half of the period for the highest skilled groups, with a stronger positive effect apparent in the higher intermediate group. Therefore the French results also suggest a lagged response, a similar conclusion to that found for the UK.

Finally Table 5 shows that in the case of Germany, the evidence suggests that any skill bias is more spread across skill groups, given significant and positive impact of ICT intensity on in all intermediate skill groups. This is counterbalanced by a large negative coefficient in the lowest skill group. As in the case of France, a strong skill bias effect is not so clear in the higher skilled group; this is perhaps a feature of the German education system which places considerable emphasis on the intermediate technical skills. There is some evidence to indicate the presence of skill-capital complementarity in the higher intermediate skill levels, though this is not strong in the highest or the lowest skill groups. The introduction of a breakpoint in 1989 shows that the capital skill complementarity effect is strongest in the latter half of the period, whereas the impact of ICT intensity appears to be evenly spread over the two periods. Therefore in Germany ICT seems to have hastened the move away from those with very low qualifications but not favoured any particular skill group. Thus the lagged response story is not so apparent for this country. Unfortunately without further information it is unclear whether this is the result of greater use of intermediate skilled workers in ICT-related jobs or whether Germany has lower adoption rates overall. The evidence to date seems to favour the latter suggestion; for example, Mason and O’Mahony (2004) show lower growth rates of ICT capital per hour and smaller levels and lower proportions of IT workers in the labour force in Germany than in the US, the UK or France.

Overall therefore, employment share equations offer some insight into the pattern of skill use within each country. An interesting story is emerging from the US, suggesting that the demand for skilled labour associated with ICT, far from accelerating, appears to have disappeared in the later period; this observation has also been noted in Beaudry and Green (2002). In contrast, ICT appears to have less of an impact on relative demands for skilled workers in two of the European countries in the 1980s but it has raised the demand for high skilled workers and lowered that for the unskilled in the 1990s. This is consistent with the assumption that Europe lags behind the US in both the adoption and use of ICT technology. 


\section{Wage shares}

The results from the estimation of equation 1 for US, UK and France are presented in tables 6-8, respectively. Note that initially the estimation also included relative wage terms but these terms generally did not have the expected sign. Given the likelihood that these terms were endogenous, and in line with other work in this area, they were excluded from the final model. However, we can report that the inclusion of the relative wage terms did not significantly affect the coefficients on other variables in the equations, in terms of size, sign or significance. Tables 6-8 also report wage share equations excluding the adoption term for the highest skill group, given that the high skilled IT workers form part of this higher group.

Overall, the wage share equations pick up less significant coefficients than the employment share equations. Given that they provide the net impact of technology on skills (net of supply side changes), this was expected. However, there are some interesting findings for the US. Firstly, there is little or no evidence of capital skill complementarity, in particular the positive coefficient on the highest skill group has disappeared. The wage share for the highest skilled group is significant and positively associated with ICT in the US, consistent with other studies, though again the overall significance stems only from the earlier period. For the lowest skilled group, the ICT term is negative, consistent with expectations. When this variable is considered over the two periods, the earlier period appears to have the dominant coefficients, but also in the latter period, there are significant effects in both the higher intermediate category and the unskilled. When the adoption variable is considered it can be seen that it is not significant in any of the skill groups over the full period. However when the time period is split, there is a very large and positive impact in the case of the higher and associate degree in the 1980s but this turns negative in the 1990s, although insignificant. Note that including the adoption variable for the higher skilled group does not significantly alter the coefficients so that the 1980s finding of skill biased technical progress does not appear to be due to increased use of IT specific labour. ${ }^{7}$

The wage share equations for the UK (Table 7) in many respects show a similar pattern to the employment equations. There is some evidence of capital skill complementarity in the higher skill category for the whole period. Again the technology terms are more apparent in the later period. There is little evidence of a sufficiently strong demand for highly skilled workers directly from ICT capital intensity that translates into significant wage premia over the entire period or each of the sub periods. However the adoption variable is significant for the university graduate group and the higher intermediate group. In the UK case its inclusion does have an impact on the size of

\footnotetext{
${ }^{7}$ For this statement to be conclusive however requires information on the relative wage growth of IT specific workers. In fact data from the CPS show wages of these workers have been growing faster than graduates in general but this is unlikely to drive the increased graduate cost share. IT workers represent only a small fraction of US graduates, about $7 \%$ in 2000 .
} 
the ICT intensity variable for the highest skilled group, in particular in the later period. The ICT intensity variable is negative and significant for the lowest skill group. Thus the results are broadly consistent with the lagged response story in the employment share equations but are suggestive that increased demand for skilled labour in the UK is dominated by adoption effects.

The French results, presented in Table 8, are more mixed and less supportive of a lagged response story. However, the ICT variable indicates some significant impacts on the wage shares of higher and higher intermediate skill groups (positive) as well as for the unskilled workers (negative). When considered in model 2, these effects appear to be strongest in the latter half of the period, except in the case of the highest skilled group. The adoption variable for this group is positive but not significant. The adoption variable has a negative impact on the baccalaureate shares in the 1990s but this is counterbalanced by the positive impact from the ICT term. This suggests intermediate skills are in demand for ICT use but less for adoption of the technology.

The models above may be criticised for not taking into account other factors, such as age or gender differences across industries. To control for such effects the US and UK equations were reestimated using data on the mean age of worker, the proportion of females in the workforce by industry and skill group - comparable data were not available for France and Germany. The impact of including these variables was minimal on the variables of interest in this paper - capital skill complementarity and ICT intensity. However, the coefficients on age and gender did offer some further insights. In the US employment share equations age had a significant and negative impact on the higher skilled employment shares, though intermediate skill shares appear to be positively affected by age, suggesting that experience has more of a role to play in professions where intermediate skills are dominant. The gender variable appears to have some impact on the shares of intermediate skilled individuals. In the UK, age proved to be generally insignificant in all employment equations, except in the case of the higher skilled workers in the 1990s. Gender had a negative impact on the majority of skill groups in the 1980s; however, this trend had disappeared by the 1990s. In both countries age and gender impacts were less obvious in the wage share equations, except that in the UK case gender appears to have a strongly significant negative impact on the lower skill wage shares in the earlier period, but this impact has disappeared by the 1990s.

\section{Conclusions and implications}

Overall therefore, these results suggest that employment and wage shares of skilled workers have generally been increased as a result of ICT. In summary we observe the following:

1. In all countries the lowest skilled group workers have suffered a loss of share both in employment and wage terms from the introduction of new technology. These workers have no more than the very basic educational qualifications. The sole exception is the US in the 1990s. 
2. There is evidence that ICT has had a positive impact on the employment and wage bill shares of the highest skilled group, university graduates and above, but also there has been an impact on the higher intermediate group, third level but below degree.

3. The timing of the impacts of new technology vary between countries with the US showing the largest impact in the 1980s and the European countries showing a greater impact in the 1990s. This is consistent with a lagged response story, as emphasised in the productivity literature by Basu et al. (2003).

4. The US results (and also some results for Europe) indicate that the use stage of information technology may have different implications for skill utilisation and remuneration than the adoption stage. This has implications for the General Purpose Technology literature in that it is not clear which type of skills are most appropriate for the use stage.

Overall, this paper emphasises the fact that skill requirements are likely to change through time. Acemoglu (2002) suggests that the employment structure of the US was so high-skill intensive in the 1960s and 1970s that it created the impetus for high-tech capital adoption, so as to best utilise America's abundant skill resources. In this sense technical progress is endogenous. But it may also be endogenous in the sense that the technology itself may adapt over time to skill endowments and this is likely to vary across country.

One of the many roles of policy is to identify the skill needs of a growing economy in order to ensure that the right skills are available at the right time. For this to be achieved, a better understanding of the skill requirements of the new technology (in this case, ICT) environment is necessary. In this paper there is evidence that all countries included in the analysis have experienced some degree of skill biased technological change in the past two decades. The adoption process of a new technology implies that the whole range of different skill groups may be affected at different points in time. What is clear from this paper is that more sophisticated dynamic analyses are needed to explore the changing relationship between technology use, technology adoption and skills.

\section{References}

Acemoglu, D. (2003) ‘Cross-country inequality trends’, Economic Journal, February, F121-F149

Acemoglu, D. (2002) 'Technical change, inequality and the labor market' Journal of Economic Literature, XL, 7-72.

Autor, D. H., L. F. Katz and A. B. Krueger, 1998, 'Computing inequality: Have computers changed the labour market?’, Quarterly Journal of Economics, November, 1169-1210. 
Basu, S., Fernald, J.G., Oulton, N. and Srinivasan, S. (2003), 'The Case of the Missing Productivity Growth: or does information technology explain why productivity accelerated in the US but not in the UK', NBER working paper 10010

Beaudry, P. and D. A. Green (2002) 'Changes in US wages 1976-2000: Ongoing skill bias or major technological change?' NBER working paper 8787, available at www.nber.org/papers/w8787

Berndt, E. R. (1991) The Practice of Econometrics, Classic and Contemporary, Addison Wesley, Massachusetts.

Berman, E., J. Bound and Z. Griliches (1994) 'Changes in the Demand for Skilled Labour within US manufacturing Industries: Evidence from the Annual Survey of Manufacturers', Quarterly Journal of Economics 109, pp.365-367.

Berman, E., J. Bound and S. Machin (1998) 'Implications of skill biased technological change: International Evidence’, Quarterly Journal of Economics, 113, 1169-1213.

Black, S. and L. Lynch (2001) "How to compete: the impact of workplace practices and information technology on productivity”, Review of Economics and Statistics, 83, 3: 434-445.

Bresnahan T., E. Brynjolfsson and L. Hitt (2002) "Information technology, workplace organisation and the demand for skilled labour: firm-level evidence”, Quarterly Journal of Economics, 117 (1): 339-376.

Card, D. and J. E. DiNardo (2002), 'Skill Biased Technological Change and Rising Wage Inequalities: Some Problems and Puzzles’, NBER working paper, 8769, February.

Caroli, E. and J. Van Reenen, (2001) 'Skill-Biased Organisational change? Evidence from a panel British and French Establishments', Quarterly Journal of Economics, 1449-1492.

Chennells, L. and J. van Reenen, (1999) 'Has technology hurt less skilled workers? An econometric survey of the effects of technical change on the structure of pay and jobs', IFS working paper, W99/27.

Chun, H. (2003) 'Information technology and the demand for educated workers: Disentangling the impacts of adoption versus use', The Review of Economics and Statistics, 85 (1), 1-8.

Doms, M., T. Dunne, and K. R. Troske (1997) 'Workers, wages and technology', Quarterly Journal of Economics, CXII (1), 253-290.

Goldin, C. and L. Katz (1998), 'The Origins of Technology-Skill Complementarity’, Quarterly Journal of Economics, 113, pp.693-732.

Geroski, P. A. (2000) ‘Models of technology diffusion’, Research Policy, 29, 603-625. 
Jacobebbinghaus, P. and T. Zwick (2002) 'New Technologies and the demand for medium qualified labour in Germany', Journal of Applied Social Science Studies, 122, 179-206.

Kahn, J. A. and J. Lim (1998) 'Skilled labor-augmenting technical progress in US manufacturing', Quarterly Journal of Economics, 113, 1281-1308.

O’Mahony, M. and W. de Boer (2002) Britain’s relative productivity performance: Updates to 1999 Final Report to DTI/Treasury/ONS, mimeograph.

Oulton, N, (2002), 'ICT and Productivity Growth in the United Kingdom.', Oxford Review of Economic Policy, 18, (3), pp.363-379.

Mason, G., M. O’Mahony, C. Robinson and J. Forth, (2002) 'ICT Labour and Capital Inputs and their Impact on output growth in the UK and US', Progress report to the Evidence-Based Policy Fund Research Committee, September 2002.

Mason, G. and M. O'Mahony (2004), New Research on ICT Investments, Workforce Skills and Industrial Performance in the UK: Key Findings and Policy Implications, Mimeo, NIESR

Prais, S. (1986) Comment on 'Training for Change' by Norman Davis, in P. E. Hart (Ed.), Unemployment and labour market policies, Gower Publishing, Aldershot.

Prais, S. and K. Wagner (1985) 'Schooling standards in England and Germany: some summary comparisons bearing on Economic Performance', National Institute Economic Review, May 1985, pp.53-76.

Riley, R. and G. Young (1999) 'The skill-bias of technological change in the UK, mimeograph.

Timmer, M. and M. O’Mahony (2002) 'Measuring capital input' EPKE Technical Note 1, available at http://www.niesr.ac.uk/epke/working_papers.html 
Table 1: Skills categories employed in the analysis (employment shares)*

\begin{tabular}{lccc}
\hline US & $\mathbf{1 9 8 2}$ & $\mathbf{2 0 0 0}$ \\
\hline & 16.3 & 23.2 \\
1. Bachelor degrees and above & 5.3 & 7.4 \\
2. Associate degrees & 11.9 & 16.8 \\
3. Some college, no degree & 44.4 & 35.7 \\
4. High school graduate & 22.1 & 16.9 \\
\hline 5. Did not complete high school & & \\
\hline UK & 6.9 & 16.0 \\
1. First degrees and above & 3.6 & 7.8 \\
2. Other National Vocational Qualifications: level 4 (NVQ4) & 18.1 & 29.6 \\
3. National Vocational Qualifications: level 3 (NVQ3) & 24.3 & 33.8 \\
4. National Vocational Qualifications: levels 2 and 1 (NVQ1_2) & 47.1 & 12.8 \\
5. No formal qualifications & & \\
France & 5.3 & 11.0 \\
1. Bachelor degrees and above (Higher) & 4.3 & 12.4 \\
2. Baccalaureate plus 2 years college (BD2) & 10.6 & 15.7 \\
3. Baccalaureate (BD) & 27.7 & 31.6 \\
4. Vocational (CAP) & 8.7 & 7.2 \\
5. General certificate of education (BEPC) & 43.4 & 22.1 \\
6. No formal qualifications (Aucun diplôme or CEP) & 1.7 & 4.1 \\
\hline Germany** & 2.0 & 3.3 \\
1. Bachelor degrees and above (Higher - N5) & 1.4 & 4.0 \\
2. Technical university (Fachhochschule- N4) & 0.8 & 1.7 \\
3.Vocational degree (Lehre) and university entrance degree (Abitur, 14 yrs - N3) & 66.8 \\
4.university entrance degree (Abitur Fachhochschulereife, 12-13yrs -N2) & 32.8 & 20.7 \\
5. Vocational training (Lehre) and basic intermediate education (12yrs - N1) & & \\
6. Basic or intermediate general education (9 years or less - N0) & & \\
\hline
\end{tabular}

* shares of non-agricultural market economy employment; **1998 shares.

Sources: UK: Labour force survey, ONS; US: Current Population Survey; France: unpublished data from INSEE; Germany: Employment Survey. 
Table 2: US employment share equations, 1979-2000

\begin{tabular}{|c|c|c|c|c|c|}
\hline & Higher & $\begin{array}{c}\text { Associate } \\
\text { degree }\end{array}$ & $\begin{array}{c}\text { Some college, } \\
\text { no degree }\end{array}$ & $\begin{array}{l}\text { High School } \\
\text { Graduation }\end{array}$ & $\begin{array}{c}\text { No } \\
\text { Qualifications }\end{array}$ \\
\hline \multicolumn{6}{|l|}{ Model I } \\
\hline $\mathrm{k} / \mathrm{y}$ & $\begin{array}{c}0.019^{\ddagger} \\
(0.011)\end{array}$ & $\begin{array}{c}0.002 \\
(0.003)\end{array}$ & $\begin{array}{c}0.10 \\
(0.008)\end{array}$ & $\begin{array}{c}-0.040 * \\
(0.014)\end{array}$ & $\begin{array}{c}0.008 \\
(0.006)\end{array}$ \\
\hline ICTk/K & $\begin{array}{l}0.009 * \\
(0.003)\end{array}$ & $\begin{array}{c}0.004^{*} \\
(0.001)\end{array}$ & $\begin{array}{c}0.007^{*} \\
(0.002)\end{array}$ & $\begin{array}{c}0.000 \\
(0.004)\end{array}$ & $\begin{array}{l}-0.020^{*} \\
(0.003)\end{array}$ \\
\hline \multicolumn{6}{|l|}{ Model II } \\
\hline $\mathrm{k} / \mathrm{y} * 7988$ & $\begin{array}{c}0.009 \\
(0.013)\end{array}$ & $\begin{array}{l}-0.006^{*} \\
(0.002)\end{array}$ & $\begin{array}{c}0.008 \\
(0.008)\end{array}$ & $\begin{array}{c}-0.048^{*} \\
(0.015)\end{array}$ & $\begin{array}{c}0.036^{*} \\
(0.013)\end{array}$ \\
\hline $\mathrm{k} / \mathrm{y} * 8900$ & $\begin{array}{l}0.031 * \\
(0.010)\end{array}$ & $\begin{array}{c}0.011 \\
(0.007)\end{array}$ & $\begin{array}{c}0.012 \\
(0.013)\end{array}$ & $\begin{array}{l}-0.031^{\ddagger} \\
(0.016)\end{array}$ & $\begin{array}{c}-0.024^{*} \\
(0.009)\end{array}$ \\
\hline ICTk/K*7988 & $\begin{array}{l}0.011^{*} \\
(0.002)\end{array}$ & $\begin{array}{c}0.004^{*} \\
(0.000)\end{array}$ & $\begin{array}{c}0.008^{*} \\
(0.001)\end{array}$ & $\begin{array}{c}0.008^{\ddagger} \\
(0.004)\end{array}$ & $\begin{array}{l}-0.031^{*} \\
(0.005)\end{array}$ \\
\hline ICTk/K*8900 & $\begin{array}{c}0.007 \\
(0.007)\end{array}$ & $\begin{array}{c}0.003 \\
(0.002)\end{array}$ & $\begin{array}{c}0.004 \\
(0.004)\end{array}$ & $\begin{array}{c}-0.016 \\
(0.013)\end{array}$ & $\begin{array}{c}0.001 \\
(0.004)\end{array}$ \\
\hline
\end{tabular}

NB All data are weighted, and time dummies were included for all specifications,

*: denotes rejection of the null at $5 \%$ significance level,

‡: denotes rejection of the null at $10 \%$ significance level

Table 3: UK employment share equations, 1979-2000

\begin{tabular}{lccccc}
\hline & Higher & NVQ 4 & NVQ 3 & NVQ12 & No qualifications \\
\hline Model 1 & & & & \\
\hline Capital to & $0.055^{*}$ & $0.013^{*}$ & 0.094 & -0.111 & -0.049 \\
output ratio & $(0.015)$ & $(0.006)$ & $(0.064)$ & $(0.075)$ & $(0.051)$ \\
ICT capital to & 0.003 & 0.001 & 0.004 & $0.025^{*}$ & $-0.032^{\ddagger}$ \\
total capital & $(0.003)$ & $(0.002)$ & $(0.006)$ & $(0.009)$ & $(0.016)$ \\
ratio & & & & \\
\hline Model 2 & & & & \\
\hline k/y*7988 & 0.023 & 0.016 & 0.147 & 0.010 & $-0.196^{*}$ \\
& $(0.021)$ & $(0.026)$ & $(0.108)$ & $(0.064)$ & $(0.067)$ \\
k/y*8900 & $0.064^{*}$ & 0.011 & -0.070 & -0.165 & 0.020 \\
& $(0.014)$ & $(0.013)$ & $(0.061)$ & $(0.100)$ & $(0.034)$ \\
ICTk/K*7988 & -0.007 & -0.003 & 0.005 & $0.026 *$ & -0.020 \\
& $(0.007)$ & $(0.006)$ & $(0.007)$ & $(0.005)$ & $(0.019)$ \\
ICTk/K*8900 & $0.021^{*}$ & $0.010^{*}$ & -0.002 & 0.012 & $-0.040^{*}$ \\
& $(0.006)$ & $(0.002)$ & $(0.011)$ & $(0.018)$ & $(0.019)$ \\
\hline
\end{tabular}

NB All data are weighted, and time dummies were included for all specifications

*: denotes rejection of the null at $5 \%$ significance level

$\ddagger$ denotes rejection of the null at $10 \%$ significance level 
Table 4: French employment share equations, 1982-2000

\begin{tabular}{lcccccc}
\hline & Higher & $\begin{array}{c}\text { Baccalaureate } \\
+2 \text { yrs }\end{array}$ & Baccalaureate & $\begin{array}{c}\text { Vocational } \\
\text { qualification }\end{array}$ & $\begin{array}{c}\text { General } \\
\text { Education }\end{array}$ & No qualifications \\
\hline Model 1 & & & & & & \\
\hline k/y & -0.002 & 0.000 & $0.026^{*}$ & -0.002 & 0.016 & -0.039 \\
& $(0.018)$ & $(0.017)$ & $(0.012)$ & $(0.022)$ & $(0.015)$ & $(0.039)$ \\
ICTk/K & $0.025^{\ddagger}$ & $0.034^{*}$ & 0.018 & -0.003 & 0.002 & $-0.076^{*}$ \\
& $(0.013)$ & $(0.010)$ & $(0.016)$ & $(0.020)$ & $(0.007)$ & $(0.016)$ \\
\hline Model 2 & & & & & 0.073 & $-0.124^{*}$ \\
k/y*8288 & $-0.039^{\ddagger}$ & -0.021 & $0.044^{*}$ & $0.066^{*}$ & 0.073 & $(0.050)$ \\
& $(0.022)$ & $(0.017)$ & $(0.021)$ & $(0.033)$ & $(0.042)$ & 0.002 \\
k/y*8900 & 0.016 & 0.010 & 0.017 & -0.034 & -0.011 & $(0.054)$ \\
& $(0.025)$ & $(0.023)$ & $(0.018)$ & $(0.038)$ & $(0.015)$ & $-0.086^{*}$ \\
ICTk/K*8288 & $0.021^{\ddagger}$ & $0.026^{*}$ & $0.015^{*}$ & 0.017 & 0.007 & $(0.012)$ \\
ICTk/K*8900 & $(0.012)$ & $(0.008)$ & $(0.006)$ & $(0.021)$ & $(0.012)$ & $-0.069^{*}$ \\
& $0.028^{*}$ & $0.040^{*}$ & 0.020 & -0.018 & -0.002 & $(0.016)$ \\
\hline
\end{tabular}

All data are weighted, and time dummies were included for all specifications

*: denotes rejection of the null at $5 \%$ significance level

‡: denotes rejection of the null at $10 \%$ significance level

Table 5: German employment share equations, 1979-1998

\begin{tabular}{lcccccc}
\hline & Higher & $\begin{array}{c}\text { Technical } \\
\text { degree }\end{array}$ & $\begin{array}{c}\text { Vocational } \\
\text { (high) }\end{array}$ & $\begin{array}{c}\text { Vocational } \\
\text { (intermediate) }\end{array}$ & $\begin{array}{c}\text { Vocational } \\
\text { (low) }\end{array}$ & $\begin{array}{c}\text { No } \\
\text { qualifications }\end{array}$ \\
\hline Model 1 & & & & & & \\
\hline k/y & 0.003 & $0.003^{\ddagger}$ & $0.003^{\ddagger}$ & 0.001 & 0.001 & -0.005 \\
& $(0.002)$ & $(0.002)$ & $(0.002)$ & $(0.001)$ & $(0.001)$ & $(0.006)$ \\
ICTk/K & 0.002 & $0.002^{*}$ & $0.003^{\ddagger}$ & $0.002^{*}$ & $0.002^{*}$ & $-0.030^{*}$ \\
& $(0.002)$ & $(0.001)$ & $(0.002)$ & $(0.001)$ & $(0.001)$ & $(0.005)$ \\
\hline Model 2 & & & & & & \\
\hline k/y*7988 & 0.004 & 0.002 & 0.004 & 0.001 & -0.009 & -0.003 \\
& $(0.003)$ & $(0.002)$ & $(0.004)$ & $(0.003)$ & $(0.016)$ & $(0.016)$ \\
k/y*8998 & 0.002 & $0.003^{*}$ & $0.003^{*}$ & 0.000 & -0.003 & -0.006 \\
& $(0.002)$ & $(0.002)$ & $(0.001)$ & $(0.001)$ & $(0.007)$ & $(0.005)$ \\
ICTk/K*7988 & $0.002^{\ddagger}$ & $0.002^{\ddagger}$ & $0.002^{\ddagger}$ & $0.002^{*}$ & $0.024^{*}$ & $-0.031^{*}$ \\
& $(0.001)$ & $(0.001)$ & $(0.001)$ & $(0.001)$ & $(0.005)$ & $(0.004)$ \\
ICTk/K*8998 & 0.001 & $0.002^{\ddagger}$ & $0.005^{\ddagger}$ & $0.002^{*}$ & $0.018^{*}$ & $-0.028^{*}$ \\
& $(0.003)$ & $(0.001)$ & $(0.003)$ & $(0.001)$ & $(0.008)$ & $(0.010)$ \\
\hline
\end{tabular}

All data are weighted, and time dummies were included for all specifications

*: denotes rejection of the null at $5 \%$ significance level

‡: denotes rejection of the null at $10 \%$ significance level 
Table 6: US wage share equations, 1979-2000

\begin{tabular}{lcccccc}
\hline & Higher & Higher & $\begin{array}{c}\text { Associate } \\
\text { degree }\end{array}$ & $\begin{array}{c}\text { Some college, } \\
\text { no degree }\end{array}$ & $\begin{array}{c}\text { High School } \\
\text { graduation }\end{array}$ & $\begin{array}{c}\text { No } \\
\text { qualifications }\end{array}$ \\
\hline Model 1 & & & & & \\
\hline k/y & 0.050 & 0.050 & -0.003 & -0.024 & $-0.035^{*}$ & 0.010 \\
& $(0.040)$ & $(0.041)$ & $(0.002)$ & $(0.031)$ & $(0.013)$ & $(0.013)$ \\
ICTk/K & $0.008^{*}$ & $0.008^{*}$ & $0.003^{*}$ & $0.010^{\ddagger}$ & -0.005 & $-0.017^{*}$ \\
& $(0.002)$ & $(0.002)$ & $(0.001)$ & $(0.005)$ & $(0.003)$ & $(0.003)$ \\
Adoption & - & 0.028 & -0.040 & 0.001 & 0.002 & 0.005 \\
& & $(0.229)$ & $(0.030)$ & $(0.047)$ & $(0.088)$ & $(0.161)$ \\
\hline Model 2 & & & & & $-0.036^{*}$ & $0.027^{*}$ \\
k/y*7988 & 0.011 & 0.006 & $-0.005^{*}$ & 0.008 & $(0.013)$ & $(0.011)$ \\
& $(0.011)$ & $(.009)$ & $(0.002)$ & $(0.006)$ & -0.027 & -0.014 \\
k/y*8900 & 0.103 & 0.103 & -0.001 & -0.065 & $(0.020)$ & $(0.023)$ \\
& $(0.089)$ & $(0.091)$ & $(0.006)$ & $(0.063)$ & 0.004 & $-0.023^{*}$ \\
ICTk/K*7988 & $0.011^{*}$ & $0.010^{*}$ & $0.002^{*}$ & $0.006^{*}$ & $(0.004)$ & $(0.001)$ \\
& $(0.003)$ & $(0.002)$ & $(0.001)$ & $(0.002)$ & -0.014 & $-0.010^{*}$ \\
ICTk/K*8900 & 0.004 & 0.004 & $0.004^{*}$ & 0.016 & $(0.014)$ & $(0.004)$ \\
& $(0.006)$ & $(0.006)$ & $(0.001)$ & $(0.013)$ & $-1.12^{*}$ & -0.073 \\
Adoption & - & $1.267^{*}$ & $0.103^{*}$ & -0.179 & $(0.388)$ & $(0.279)$ \\
(Eith/E)*7988 & & $(0.372)$ & $(0.044)$ & $(0.237)$ & 0.060 & 0.008 \\
Adoption & - & -0.037 & -0.047 & 0.013 & $(0.117)$ & $(0.167)$ \\
(Eith/E)*8900 & & $(0.292)$ & $(0.038)$ & $(0.057)$ & &
\end{tabular}

All data are weighted, and time dummies were included for all specifications

*: denotes rejection of the null at $5 \%$ significance level

‡: denotes rejection of the null at $10 \%$ significance level

Table 7: UK wage share equations, 1979-2000

\begin{tabular}{|c|c|c|c|c|c|c|}
\hline & Higher & Higher & NVQ 4 & NVQ 3 & NVQ21 & $\begin{array}{c}\text { No } \\
\text { qualifications }\end{array}$ \\
\hline \multicolumn{7}{|l|}{ Model 1} \\
\hline $\begin{array}{l}\text { Capital to output } \\
\text { ratio } \\
\text { ICT capital } \\
\text { intensity } \\
\text { Adoption } \\
\text { (Eith/E) }\end{array}$ & $\begin{array}{c}0.037 * \\
(0.012) \\
0.006 \\
(0.005) \\
-\end{array}$ & $\begin{array}{c}0.031^{*} \\
(0.02) \\
0.000 \\
(0.006) \\
1.336^{*} \\
(0.380) \\
\end{array}$ & $\begin{array}{c}-0.024 \\
(0.015) \\
0.002 \\
(0.003) \\
-0.174 \\
(0.118) \\
\end{array}$ & $\begin{array}{c}0.047 \\
(0.071) \\
0.000 \\
(0.004) \\
-0.426 \\
(0.312) \\
\end{array}$ & $\begin{array}{c}-0.002 \\
(0.068) \\
0.013 \\
(0.015) \\
-1.302^{*} \\
(0.618) \\
\end{array}$ & $\begin{array}{c}-0.053 \\
(0.047) \\
-0.016 \\
(0.011) \\
0.218 \\
(0.494) \\
\end{array}$ \\
\hline \multicolumn{7}{|l|}{ Model 2} \\
\hline K/y*7988 & $\begin{array}{c}0.047^{\ddagger} \\
(0.027)\end{array}$ & $\begin{array}{c}0.046^{\ddagger} \\
(0.027)\end{array}$ & $\begin{array}{c}-0.019 \\
(0.014)\end{array}$ & $\begin{array}{c}0.203 \\
(0.129)\end{array}$ & $\begin{array}{c}-0.080 * \\
(0.033)\end{array}$ & $\begin{array}{l}-0.150^{\ddagger} \\
(0.090)\end{array}$ \\
\hline K/y*8900 & $\begin{array}{c}0.035^{\ddagger} \\
(0.019)\end{array}$ & $\begin{array}{c}0.023 \\
(0.023)\end{array}$ & $\begin{array}{l}-0.029 \\
(0.025)\end{array}$ & $\begin{array}{l}-0.048 \\
(0.061)\end{array}$ & $\begin{array}{c}0.053 \\
(0.109)\end{array}$ & $\begin{array}{l}-0.001 \\
(0.018)\end{array}$ \\
\hline ICTk/K*7988 & $\begin{array}{l}-0.008 \\
(0.013)\end{array}$ & $\begin{array}{l}-0.008 \\
(0.013)\end{array}$ & $\begin{array}{c}0.004 \\
(0.003)\end{array}$ & $\begin{array}{c}0.008 \\
(0.005)\end{array}$ & $\begin{array}{c}0.003 \\
(0.004)\end{array}$ & $\begin{array}{l}-0.007 \\
(0.019)\end{array}$ \\
\hline ICTk/K ${ }^{* 8900}$ & $\begin{array}{c}0.026 \\
(0.022)\end{array}$ & $\begin{array}{c}0.008 \\
(0.010)\end{array}$ & $\begin{array}{l}-0.007 \\
(0.006)\end{array}$ & $\begin{array}{l}-0.026^{*} \\
(0.013)\end{array}$ & $\begin{array}{c}0.047^{\ddagger} \\
(0.026)\end{array}$ & $\begin{array}{l}-0.022 * \\
(0.008)\end{array}$ \\
\hline Adoption*7988 & - & $\begin{array}{c}0.405 \\
(0.862)\end{array}$ & $\begin{array}{l}-0.665 \\
(0.504)\end{array}$ & $\begin{array}{l}-0.490 \\
(0.942)\end{array}$ & $\begin{array}{l}0.463 \\
(1.17)\end{array}$ & $\begin{array}{c}0.386 \\
(0.870)\end{array}$ \\
\hline Adoption*8900 & - & $\begin{array}{l}1.659 * \\
(0.480)\end{array}$ & $\begin{array}{l}0.653^{*} \\
(0.265)\end{array}$ & $\begin{array}{c}0.106 \\
(0.486)\end{array}$ & $\begin{array}{l}-2.57 \\
(1.60)\end{array}$ & $\begin{array}{c}0.147 \\
(0.474)\end{array}$ \\
\hline
\end{tabular}

\footnotetext{
All data are weighted, and time dummies were included for all specifications

*: denotes rejection of the null at 5\% significance level

‡: denotes rejection of the null at $10 \%$ significance level
} 
Table 8: French wage share equations, 1982-2000

\begin{tabular}{|c|c|c|c|c|c|c|c|}
\hline & Higher & Higher & $\begin{array}{c}\text { Baccalaureate } \\
+2 \mathrm{yrs}\end{array}$ & $\begin{array}{l}\text { Bacca- } \\
\text { laureate }\end{array}$ & $\begin{array}{c}\text { Vocation } \\
\text { al } \\
\text { qualificat } \\
\text { ion }\end{array}$ & $\begin{array}{c}\text { General } \\
\text { Education }\end{array}$ & $\begin{array}{c}\text { No } \\
\text { qualification } \\
\mathrm{s}\end{array}$ \\
\hline Model 1 & & & & & & & \\
\hline $\mathrm{k} / \mathrm{y}$ & $\begin{array}{l}-0.008 \\
(0.018)\end{array}$ & $\begin{array}{l}-0.008 \\
(0.019)\end{array}$ & $\begin{array}{c}0.010 \\
(0.020)\end{array}$ & $\begin{array}{c}0.036 \\
(0.022)\end{array}$ & $\begin{array}{l}-0.033 \\
(0.046)\end{array}$ & $\begin{array}{l}-0.016 \\
(0.016)\end{array}$ & $\begin{array}{c}0.010 \\
(0.033)\end{array}$ \\
\hline ICTk/K & $\begin{array}{l}0.030 * \\
(0.008)\end{array}$ & $\begin{array}{l}0.024^{*} \\
(0.008)\end{array}$ & $\begin{array}{l}0.040^{*} \\
(0.002)\end{array}$ & $\begin{array}{c}0.014 \\
(0.010)\end{array}$ & $\begin{array}{l}-0.009 \\
(0.017)\end{array}$ & $\begin{array}{l}-0.011 \\
(0.010)\end{array}$ & $\begin{array}{l}-0.059 * \\
(0.020)\end{array}$ \\
\hline Adoption & - & $\begin{array}{l}0.559 * \\
(0.175)\end{array}$ & $\begin{array}{c}-0.033 \\
(0.192)\end{array}$ & $\begin{array}{l}-0.608 \\
(0.525)\end{array}$ & $\begin{array}{l}-0.740 * \\
(0.258)\end{array}$ & $\begin{array}{l}0.695 * \\
(0.188)\end{array}$ & $\begin{array}{c}0.126 \\
(0.109)\end{array}$ \\
\hline Model 2 & & & & & & & \\
\hline $\mathrm{K} / \mathrm{y} * 8288$ & $\begin{array}{l}-0.066^{\ddagger} \\
(0.033)\end{array}$ & $\begin{array}{l}-0.063^{*} \\
(0.026)\end{array}$ & $\begin{array}{c}0.007 \\
(0.009)\end{array}$ & $\begin{array}{l}0.116^{*} \\
(0.042)\end{array}$ & $\begin{array}{c}0.005 \\
(0.024)\end{array}$ & $\begin{array}{l}-0.001 \\
(0.029)\end{array}$ & $\begin{array}{l}-0.063 \\
(0.042)\end{array}$ \\
\hline $\mathrm{K} / \mathrm{y} * 8900$ & $\begin{array}{c}0.016 \\
(0.022)\end{array}$ & $\begin{array}{c}0.016 \\
(0.022)\end{array}$ & $\begin{array}{c}0.009 \\
(0.026)\end{array}$ & $\begin{array}{c}0.002 \\
(0.021)\end{array}$ & $\begin{array}{l}-0.043 \\
(0.061)\end{array}$ & $\begin{array}{l}-0.024 \\
(0.018)\end{array}$ & $\begin{array}{c}0.040 \\
(0.037)\end{array}$ \\
\hline ICTk/K*8288 & $\begin{array}{l}0.031^{*} \\
(0.014)\end{array}$ & $\begin{array}{l}0.032 * \\
(0.014)\end{array}$ & $\begin{array}{c}0.018 \\
(0.005)\end{array}$ & $\begin{array}{l}-0.001 \\
(0.010)\end{array}$ & $\begin{array}{c}0.007 \\
(0.025)\end{array}$ & $\begin{array}{c}-0.012^{\ddagger} \\
(0.007\end{array}$ & $\begin{array}{l}-0.044^{*} \\
(0.022)\end{array}$ \\
\hline ICTk/K ${ }^{* 8900}$ & $\begin{array}{l}0.024 * \\
(0.009)\end{array}$ & $\begin{array}{c}0.012 \\
(0.010)\end{array}$ & $\begin{array}{l}0.063^{*} \\
(0.005)\end{array}$ & $\begin{array}{l}0.037^{*} \\
(0.016)\end{array}$ & $\begin{array}{l}-0.013 \\
(0.010)\end{array}$ & $\begin{array}{l}-0.013 \\
(0.021)\end{array}$ & $\begin{array}{l}-0.087 * \\
(0.013)\end{array}$ \\
\hline $\begin{array}{l}\text { Adoption } \\
(\text { Eith/E)*8288 }\end{array}$ & - & $\begin{array}{c}0.301 \\
(1.234)\end{array}$ & $\begin{array}{l}0.696 * \\
(0.239)\end{array}$ & $\begin{array}{c}0.172 \\
(0.417)\end{array}$ & $\begin{array}{c}- \\
0.105 \\
(0.54 \\
1)\end{array}$ & $\begin{array}{c}0.072 \\
(0.352 \\
)\end{array}$ & $\begin{array}{c}-1.135 \\
(1.212)\end{array}$ \\
\hline $\begin{array}{l}\text { Adoption } \\
(\text { Eith/E)*8900 }\end{array}$ & - & $\begin{array}{c}0.700 \\
(0.611)\end{array}$ & $\begin{array}{l}-0.436 \\
(0.368)\end{array}$ & $\begin{array}{c}-1.014^{*} \\
(0.398)\end{array}$ & $\begin{array}{l}-0.998^{*} \\
(0.317)\end{array}$ & $\begin{array}{l}0.987 * \\
(0.293)\end{array}$ & $\begin{array}{l}0.763 * \\
(0.327)\end{array}$ \\
\hline
\end{tabular}

